\title{
Teka-teki Unsur Kimia sebagai Media Pembelajaran Kimia Interaktif bagi siswa SMA Kelas X Berbasis Android
}

\author{
Isvandiari Fitri Utami, Kodrat Iman Satoto, Kurniawan Teguh Martono \\ Program Studi Sistem Komputer Fakultas Teknik Universitas Diponegoro \\ Jalan Prof. Sudharto, Tembalang, Semarang, Indonesia \\ isvandiarifutami@gmail.com
}

\begin{abstract}
Abstrak - Unsur kimia yang terdiri dari banyak unsur sering membuat siswa malas dengan mata pelajaran kimia khususnya dalam hal menghafal sistem periodik unsur kimia. Terkait dengan masalah ini, salah satu solusi yang ditawarkan adalah melalui media pembelajaran. Salah satu cara untuk membantu siswa melalui media pembelajaran dapat dilakukan dengan memanfaaatkan teknologi smartphone yang telah banyak dimiliki. Melihat banyaknya siswa yang telah menggunakan smartphone setiap harinya memungkinkan untuk memadukan kedua hal tersebut, sehingga siswa tidak hanya menggunakan smartphone sebagai sarana komunikasi, sosial media dan bermain game, tetapi dapat dialihkan menjadi sebuah inovasi positif dalam hal edukasi untuk menunjang sistem belajar yang interaktif. Tujuan dari penelitian ini adalah membuat aplikasi teka-teki unsur kimia sebagai media pembelajaran kimia interaktif bagi siswa SMA kelas $X$ berbasis android. Salah satu manfaat dari penelitian ini adalah hasil penelitian dapat dijadikan rujukan bagi perkembangan dunia teknologi dan berguna juga untuk menjadi referensi bagi mahasiswa yang melakukan pengembangan produk teknologi khususnya mengenai media pembelajaran berbasis android.
\end{abstract}

Dalam melakukan penelitian ini, aplikasi dibangun dengan menggunakan metode pengembangan multimedia development life cycle, data dan informasi mengenai unsurunsur kimia dalam sistem periodik unsur diperoleh dari buku materi kimia SMA kelas X berdasarkan kurikulum 2006, beberapa jurnal, dan dari pengajar kimia untuk materi SMA kelas X secara langsung. Pada tahapan implementasi, program dibuat dengan drag and drop serta menggunakan bahasa pemrograman Javascript. Pengujian yang dilakukan pada aplikasi adalah dengan menggunakan metode whitebox.

Berdasarkan hasil pengujian yang dilakukan pada aplikasi teka-teki unsur kimia sebagai media pembelajaran kimia interaktif berbasis aplikasi android, aplikasi sudah mampu berjalan cukup maksimal. Hasil pengujian mampu menampilkan pembelajaran kimia dengan materi sistem periodik unsur, menampilkan soal latihan dari materi yang telah dipaparkan pada menu belajar dan memberikan respon jawaban kepada pengguna berupa jawaban benar maupun salah.

Kata kunci : Media Pembelajaran, Sistem Periodik Unsur, Multimedia Development Life Cycle, WhiteBox

\section{Pendahuluan}

$\mathrm{D}$ UNIA pendidikan terus bergerak secara dinamis, khususnya untuk menciptakan media, metode, dan materi pendidikan yang semakin interaktif dan komperhensif. Media yang secara lazim tersedia antara lain: buku, majalah, jurnal, koran, tabloid untuk media offline, radio, TV, dan terakhir internet sebagai media online ${ }^{[1]}$.

Tingkat perkembangan perangkat bergerak yang sangat tinggi, tingkat penggunaan yang relatif mudah, dan harga perangkat yang semakin terjangkau, dibanding perangkat komputer personal, merupakan faktor pendorong yang semakin memperluas kesempatan penggunaan atau penerapan mobile learning sebagai sebuah kecenderungan baru dalam belajar, yang membentuk paradigma pembelajaran yang dapat dilakukan dimanapun dan kapanpun. Berdasarkan hasil tanya jawab dengan guru kimia kelas X di SMA Institut Indonesia Semarang, peranan media pembelajaran sangat membantu khususnya dalam menyampaikan materi kimia yang susah dihapal. Media pembelajaran yang digunakan pun sangat beragam mulai dari pemaparan materi dengan gambar secara langsung di kelas, praktik menggunakan media sterofoam dan tusuk gigi untuk materi ion, dan presentasi dengan menggunakan Microsoft Power Point dengan bantuan laptop dan LCD.

Ketika siswa merasa tertarik dengan media yang digunakan, maka siswa merasa lebih nyaman untuk belajar dengan media tersebut. Hal ini sangat memberikan respon positif karena siswa dapat memahami konsep yang disampaikan di dalam media dan menumbuhkan semangat belajar siswa terhadap materi kimia yang sulit dihapal. Namun, dewasa ini siswa-siswa lebih dekat dengan smartphone. Hampir semua siswa SMA mempunyai smartphone, oleh karena itu, pendekatan pembelajaran dengan menggunakan smartphone menjadi pertimbangan dari penelitian ini untuk mengembangkan aplikasi mobile learning berbasis android sebagai daya dukung pembelajaran kimia untuk siswa SMA kelas X. Hasil dari penelitian ini diharapkan dapat memberikan solusi bagi siswa dalam belajar kimia dengan praktis dan nyaman.

Dalam pembuatan tugas akhir ini pembahasan masalah memiliki batasan pada permasalahan berikut :

a. Aplikasi teka-teki unsur kimia dirancang dan dibuat berbasis aplikasi android dengan menggunakan Mobione Studio. 
b. Fitur aplikasi teka-teki unsur kimia sebagai media pembelajaran kimia interaktif bagi siswa SMA kelas X meliputi pertanyaan seputar tujuh golongan utama dari sistem periodik unsur berupa pencocokan nama dengan simbol, simbol dengan nama, nomor atom, dan periode yang berupa tekateki atau teka-teki.

c. Lingkup materi kimia hanya meliputi sistem periodik unsur, golongan utama, yaitu golongan alkali, alkali tanah, boron, karbon, nitrogen, oksigen atau kalkogen, halogen, gas mulia, unsur transisi periode keempat, dan unsur-unsur metaloid yang mengacu pada materi kimia SMA kelas X berdasarkan kurikulum 2006.

\section{LANDASAN TEORI}

\section{A. Multimedia}

Multimedia adalah penggunaan komputer untuk menyajikan dan menggabungkan teks, suara , gambar, animasi dan video dengan alat bantu dan koneksi internet sehingga pengguna dapat bernavigasi, berinteraksi, berkarya dan berkomunikasi ${ }^{\text {[2]. }}$

Multimedia dapat dikategorikan menjadi 2 macam, yaitu multimedia linier dan multimedia interaktif. Multimedia linier adalah suatu multimedia yang tidak dilengkapi dengan alat pengontrol apapun yang dapat dioperasikan oleh pengguna. Multimedia ini berjalan sekuensial (berurutan / lurus), contohnya : TV dan film.

Sedangkan multimedia interaktif adalah suatu multimedia yang dilengkapi dengan alat pengontrol (atau alat bantu berupa komputer, mouse, keyboard dan lain-lain) yang dapat dioperasikan oleh pengguna, sehingga pengguna dapat memilih apa yang diinginkan untuk proses selanjutnya. Contohnya seperti aplikasi game. Multimedia interaktif menggabungkan dan mensinergikan semua media yang terdiri dari teks, grafik, audio, dan interaktivitas.

Multimedia dapat disajikan dalam beberapa metode, antara lain :

- Berbasis kertas (Paper-based), contoh : buku, majalah, brosur.

- Berbasis cahaya (Light-based), contoh : slideshows, transparansi.

- Berbasis suara (Audio-based), contoh : CD Players, tape recorder, radio.

- Berbasis gambar bergerak (Moving-image-based), contoh : televisi, VCR (Video Cassete Recorder).

- Berbasis Digital (Digitally-based), contoh : komputer.

\section{B. Media Pembelajaran}

Media pembelajaran merupakan media yang digunakan dalam pembelajaran, yaitu meliputi alat bantu guru dalam mengajar serta sarana pembawa pesan dari sumber belajar ke penerima pesan belajar ${ }^{[3]}$. Sebagai penyaji dan penyalur pesan, media belajar dalam hal-hal tertentu bisa mewakili guru menyajikan informasi belajar kepada siswa. Jika program media itu didesain dan dikembangkan secara baik, maka fungsi itu akan dapat diperankan oleh media meskipun tanpa keberadaan guru.

\section{Multimedia Pembelajaran Interaktif}

Multimedia interaktif adalah suatu multimedia yang dilengkapi dengan alat pengontrol yang dapat dioperasikan oleh pengguna, sehingga pengguna dapat memilih apa yang dikehendaki untuk proses selanjutnya. Contoh: multimedia interaktif adalah pembelajaran interaktif, aplikasi permainan ${ }^{[4]}$. Sedangkan pembelajaran diartikan sebagai proses penciptaan lingkungan yang memungkinkan terjadinya proses belajar.

\section{Aplikasi Android}

Android adalah sebuah sistem operasi untuk perangkat mobile berbasis linux yang mencakup sistem operasi, middleware dan aplikasi. Android menyediakan platform terbuka bagi para pengembang untuk menciptakan aplikasi mereka. Awalnya, Google Inc. membeli Android Inc. yang merupakan pendatang baru yang membuat piranti lunak untuk ponsel/smartphone.

Kemudian untuk mengembangkan Android, dibentuklah Open Handset Alliance, konsorsium dari 34 perusahaan piranti keras, piranti lunak, dan telekomunikasi termasuk Google, HTC, Intel, Motorola, Qualcomm, T-Mobile, dan Nvidia. Secara garis besar, arsitektur Android dapat dijelaskan dan digambarkan sebagai berikut:

- Applications dan Widgets

Applications dan Widgets ini adalah layer dimana berhubungan dengan aplikasi saja, dimana biasanya download aplikasi dijalankan kemudian dilakukan instalasi dan jalankan aplikasi tersebut.

- Applications Frameworks Applications frameworks ini adalah layer di mana para pembuat aplikasi melakukan pengembangan/pembuatan aplikasi yang akan dijalankan di sistem operasi Android, karena pada layer inilah aplikasi dapat dirancang dan dibuat, seperti contect providers yang berupa sms dan panggilan telepon.

\section{- Libraries}

Libraries ini adalah layer di mana fitur-fitur Android berada, biasanya para pembuat aplikasi mengakses libraries untuk menjalankan aplikasinya. Berjalan diatas kernel, Layer ini meliputi berbagai library $\mathrm{C} / \mathrm{C}++$ inti seperti Libc dan SSL.

- Android Run Time Layer

Layer yang membuat aplikasi Android dapat dijalankan dimana dalam prosesnya menggunakan Implementasi Linux.

- Linux Kernel

Linux Kernel merupakan dimana inti dari operating system dari Android itu berada. Berisi file-file sistem yang mengatur sistem processing, memory, resource, drivers, dan sistem-sistem operasi android lainnya. 
Linux kernel yang digunakan android adalah linux kernel release 2.6 . $^{[5]}$

\section{E. MobiOne Studio}

MobiOne Studio merupakan persngkat lunak yang menandai masuknya Genuitec ke dalam dunia pengembangan mobile yang selalu berubah. Hal itu memberikan kemudahan bagi non-developer untuk membuat aplikasi mobile sederhana. Akan tetapi, dalam dunia nyata perusahaan mobile, dibutuhkan yang lebih daripada yang dapat disediakan oleh MobiOne Studio. Kabar baiknya adalah bahwa MobiOne membuka pintu untuk aplikasi hybrid dan membangun kapabilitas pada Windows dan Mac. Dengan MyEclipse Mobile Tools, dapat diintegrasikan kemampuan terobosan dengan keperluan backend Java EE untuk aplikasi mobile perusahaan teknologi yang siap ${ }^{[6]}$. Dalam penelitian ini pemrograman yang dilakukan adalah dengan cara drag and drop.

\section{F. Intel $X D K$}

Intel ${ }^{\circledR}$ XDK merupakan lingkungan pengembangan crossplatform yang komprehensif untuk penciptaan, pengujian, debugging, pembangunan, dan penyebaran berbasis web HTML5 dan aplikasi mobile hybrid yang efektif. ${ }^{[7]}$

\section{G. Metode Pengembangan Multimedia}

Metode yang digunakan dalam pengembangan aplikasi pembelajaran unsur kimia ini adalah Multimedia Development Life Cycle yang terdiri dari enam tahap pengembangan, yaitu Concept, Design, Material Collecting, Assembly, Testing, dan Distribution. ${ }^{[8]}$

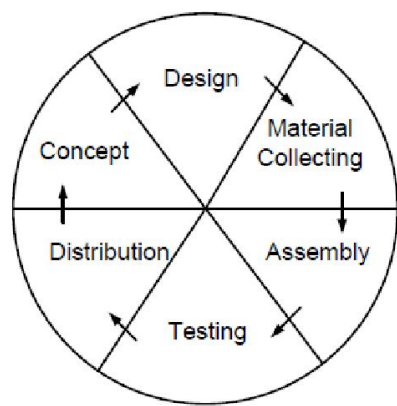

Gambar 1. Metode Pengembangan Multimedia

\section{Concept (Konsep)}

Tahap concept merupakan tahap penentuan tujuan, termasuk identifikasi audiens, macam aplikasi (presentasi, interaktif, dan lain-lain), tujuan aplikasi (informasi, hiburan, pelatihan, dan lain-lain) dan spesifikasi umum. Keluaran dari tahap concept ini biasanya berupa dokumen dengan penulisan yang bersifat naratif yang mendeskripsikan proyek multimedia secara garis besar yang memudahkan dalam pengerjaan proyek multimedia pada tahap-tahap selanjutnya.

2. Design (Perancangan)

Pada tahap design atau perancangan ini akan diuraikan secara rinci mengenai arsitektur proyek, gaya, dan kebutuhan material untuk proyek multimedia. Apabila telah diuraikan secara detail dan rinci, maka pada tahap selanjutnya yaitu material collecting dan assembly tidak akan banyak muncul keputusan baru yang berupa perubahan ataupun penambahan atau penghapusan materi yang dibutuhkan sehingga memudahkan kelancaran proyek multimedia.

\section{Material Collecting (Pengumpulan Bahan)}

Tahap pengumpulan bahan dapat dilakukan bersamaan dengan tahap Assembly atau pembuatan. Pada tahap ini dilakukan pengumpulan bahan yang dibutuhkan seperti gambar, video, audio, editing animasi, dan sebagainya.

\section{Assembly (Pembuatan)}

Tahap ini merupakan tahap inti dari pengerjaan proyek multimedia yaitu pembuatan. Pada tahap ini seluruh objek dan pengerjaannya dibuat. Assembly dilakukan berdasarkan apa yang sudah dibuat terlebih dahulu pada tahap design.

\section{Testing (Uji Coba)}

Setelah aplikasi selesai dibuat, tahap selanjutnya adalah untuk menguji kemampuan dan kinerja dari aplikasi tersebut, apakah sudah sesuai dengan yang diharapkan. Disini dapat diteliti kembali (recompile) apakah semua link, tombol, dan fitur-fitur lainnya dapat berfungsi dengan baik.

6. Distribution (Distribusi)

Tahapan dimana aplikasi disimpan dalam suatu media penyimpanan. Pada tahap ini jika media penyimpanan tidak cukup untuk menampung aplikasinya, maka dilakukan kompresi terhadap aplikasi tersebut.

\section{H. Sistem Periodik}

Sistem periodik unsur adalah suatu daftar unsur-unsur yang disusun dengan aturan tertentu. Semua unsur yang sudah dikenal ada dalam daftar tersebut. ${ }^{[9]}$ Sistem Periodik yang dipakai sekarang ini adalah sistem periodik bentuk panjang yang disusun berdasarkan kenaikan nomor atom unsur, serta mengikuti aturan Aufbau dan aturan Hund.

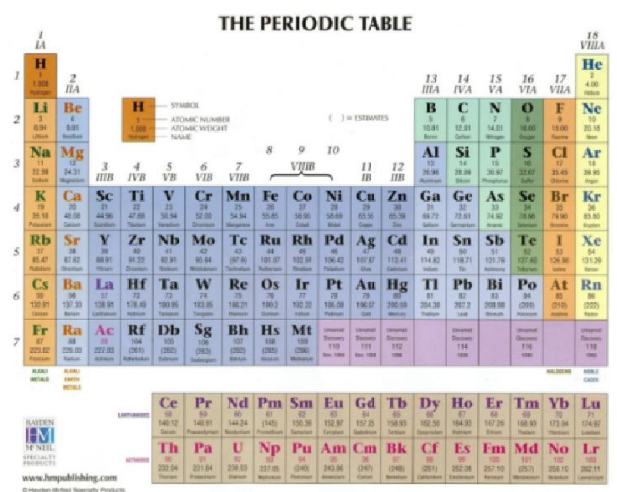

Gambar 2. Tabel Sistem Periodik Unsur 
Unsur-unsur dalam sistem periodik unsur (SPU) dapat dikelompokkan dalam periode dan golongan. Pengelompokan secara horizontal disebut dengan periode yang terdiri dari 7 periode, sedangkan pengelompokan secara vertikal disebut dengan golongan yang terdiri atas 2 golongan yaitu A dan B. Golongan merupakan kelompok unsur yang memiliki konfigurasi elektron terluar sama, sedangkan periode merupakan kelompok unsur yang memiliki kulit atom terluar (n) sama.

Unsur-unsur pada golongan A disebut unsur-unsur representatif (unsur-unsur utama) yang terdiri dari 8 golongan yaitu golongan IA-VIIIA. Unsur-unsur pada golongan B disebut unsur-unsur transisi yang terdiri dari 8 golongan yaitu IB-VIIIB.

\section{PERANCANGAN SISTEM}

\section{A. Konsep (Concept)}

Konsep media pembelajaran pendamping yang dibuat adalah bagaimana menyajikan sebuah materi pembelajaran interaktif pendamping yang dapat mempermudah siswa dan guru. Pembelajaran interaktif ini bertujuan untuk menarik minat belajar siswa SMA yang umumnya dekat sekali dengan smartphone agar dapat dengan mudah menerima materi kimia sistem periodik unsur serta dapat belajar secara mandiri kapanpun dan dimanapun.

Tahap awal dalam perancangan dibuat sebuah struktur navigasi yang berisi bagian-bagian dari aplikasi. Struktur navigasi ditunjukkan oleh Gambar 3.

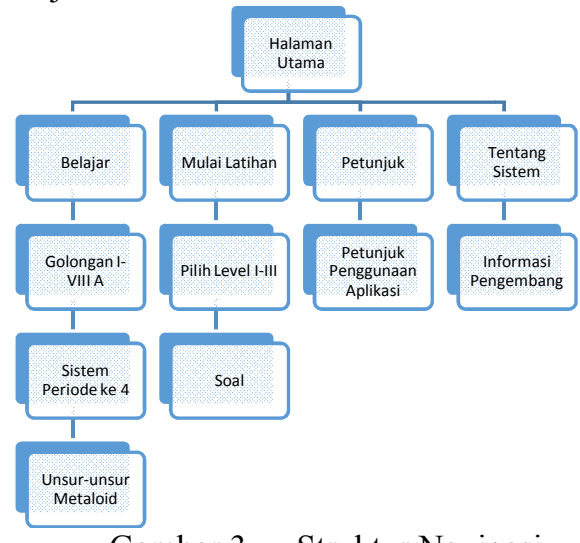

Gambar 3. Struktur Navigasi

Setelah pembuatan struktur navigasi yang dapat menjelaskan bagian-bagian dari aplikasi, maka dilanjutkan dengan perancangan dengan UML. UML yang dibuat pada aplikasi yang mempunyai 4 menu utama yaitu menu Belajar, menu Mulai Latihan, menu Petunjuk dan menu Tentang Sistem ini adalah Activity dan Sequence Diagram.

Menu Belajar pada aplikasi yang dibuat akan menampilkan tabel SPU lengkap serta gambar pilihan golongan dari golongan utama sampai unsur-unsur metaloid. Ikon dari setiap golongan ketika ditekan maka akan menampilkan layar berisi materi kimia yang sesuai dengan nama dari golongan tersebut. Activity Diagram menu Belajar ditunjukkan oleh Gambar 4.

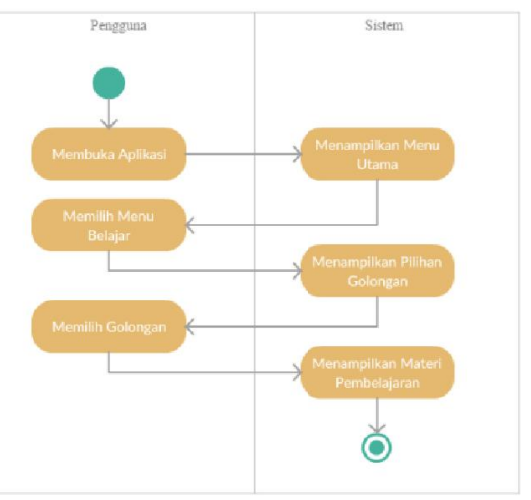

Gambar 4. Activity Diagram menu Belajar

Menu awal Mulai Latihan pada aplikasi ini akan menampilkan sebuah halaman untuk memilih level yang diinginkan. Pada halaman ini dapat dipilih menu level satu hingga level empat, dimana pada setiap level akan menampilkan teka-teki yang akan mencocokkan nama unsur dengan simbol unsur, simbol unsur dengan nama unsur, nama unsur dengan nomor atom, ataupun nama unsur dengan periode.

Activity Diagram pada menu awal Mulai Latihan ditunjukkan oleh Gambar 5.

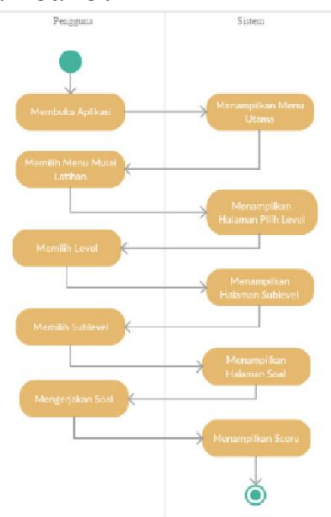

Gambar 5. Activity Diagram Menu Mulai Latihan

Menu Petunjuk disediakan untuk mempermudah pengguna dalam menggunakan fungsi-fungsi yang tersedia pada aplikasi agar dapat dimanfaatkan dengan baik. Activity Diagram pada menu Petunjuk ditunjukkan oleh Gambar 6.

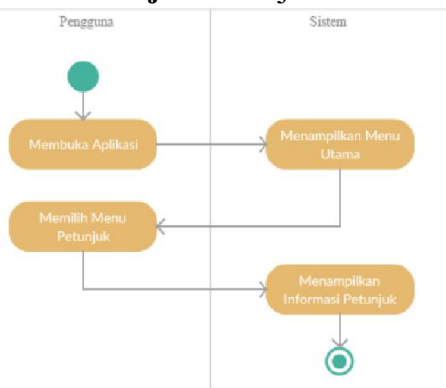

Gambar 6. Activity Diagram Menu Petunjuk 
Menu Tentang Sistem berisi mengenai profil atau informasi pengembang aplikasi ini. Activity Diagram pada menu Tentang Sistem ditunjukkan oleh Gambar 7.

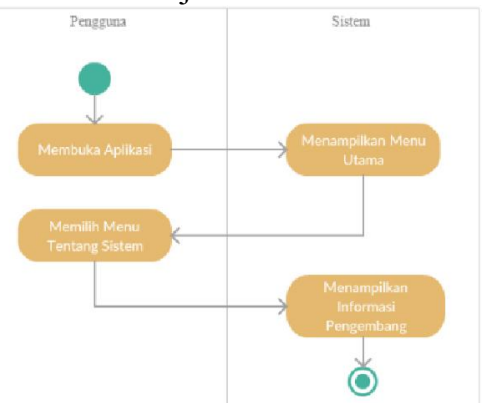

Gambar 7. Activity Diagram Menu Tentang Sistem

Langkah selanjutnya setelah pembuatan struktur navigasi dan Activity Diagram, adalah pembuatan sequence diagram. Perancangan Sequence Diagram menu Belajar ditunjukkan oleh Gambar 8.

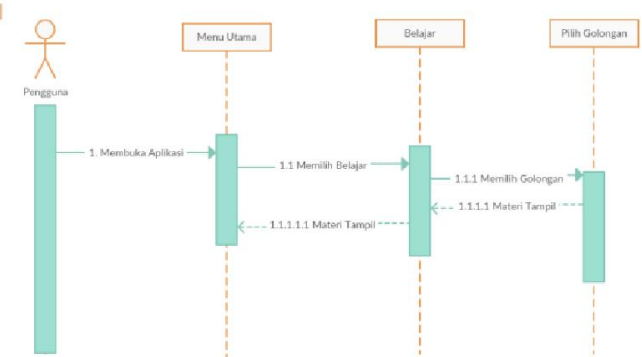

Gambar 8. Sequence Diagram Menu Belajar.

Menu Mulai Latihan berisi empat pilihan level yang dapat dipilih oleh pengguna. Setelah pengguna memilih level, pengguna dapat menjawab pertanyaan yang ada pada aplikasi berkaitan dengan materi yang ada pada aplikasi pada menu Belajar.

Menu Mulai Latihan ini menyediakan jawaban berupa pilihan ganda yang dapat dipilih oleh pengguna sebagai jawaban yang dianggap benar dari pertanyaan yang tersedia. Setelah jawaban dipilih, maka sistem akan merespon dengan memberikan score 1 apabila hasil jawaban benar dan akan merujuk ke soal selanjutnya dan memberikan score 0 apabila jawaban salah. Perancangan Sequence Diagram menu Mulai Latihan ditunjukkan oleh Gambar 9.

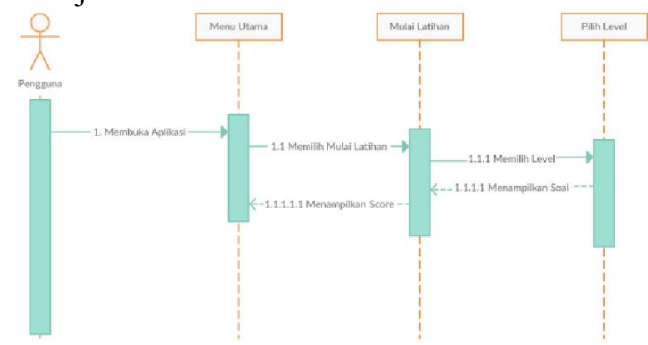

Gambar 9. Sequence Diagram Menu Mulai Latihan.
Perancangan Sequence Diagram menu Petunjuk berisi mengenai aturan penggunaan aplikasi. Perancangan Sequence Diagram Menu Petunjuk ditunjukkan oleh Gambar 10.

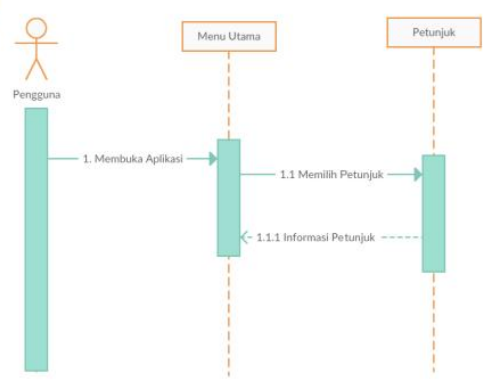

Gambar 10. Sequence Diagram Menu Petunjuk.

Menu Tentang Sistem yang menampilkan informasi program ditunjukkan oleh Gambar 11.

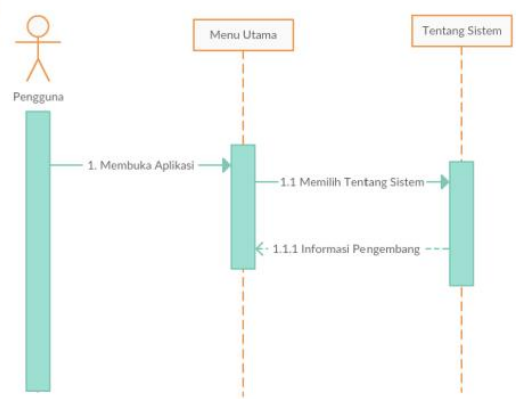

Gambar 11. Sequence Diagram Menu Tentang Sistem.

\section{B. Pengumpulan Materi (Material Collecting)}

Dalam tahapan pengumpulan materi beberapa hal yang dilakukan adalah melakukan analisis terhadap kebutuhan apa saja yang diperlukan oleh sistem, sehingga dalam pengerjaan aplikasi nantinya dapat memperoleh hasil yang diinginkan. Analisis kebutuhan yang dilakukan diantaranya dengan mencari dan memperoleh informasi yang berkaitan dengan materi-materi kimia yang diajarkan di sekolah, khususnya untuk siswa kelas X berdasarkan kurikulum 2006. Informasi tersebut akan digunakan sebagai materi pada menu belajar yang memuat tahap pembelajaran kimia sistem periodik unsur dari golongan IA hingga VIIIA, materi untuk golongan transisi periode empat, serta unsur-unsur metaloid.

Konten-konten yang diperlukan seperti Sequence Diagram menu untuk memilih golongan dan kolom keterangan tiap unsur telah dibuat sendiri untuk aplikasi ini. Sedangkan untuk gambar diagram kulit elektron, grafik atau gambar-gambar lain dan konten materi kimia pada menu belajar dan mulai latihan diambil dari sumber buku bahan ajar Kimia Untuk SMA Kelas XI oleh Michael Purba yang diterbitkan pada tahun 2006 oleh penerbit Erlangga, buku Mudah dan Aktif Belajar Kimia 3 Untuk Kelas XII Sekolah Menengah Atas / Madrasah Aliyah Program Ilmu Pengetahuan Alam oleh Yayan Sunarya dan Setiabudi Agus yang diterbitkan pada tahun 2009 oleh penerbit Pusat Perbukuan, Kementrian Pendidikan Nasional. 


\section{Pembuatan (Assembly)}

Perangkat keras dan perangkat lunak yang digunakan untuk membuat aplikasi pembelajaran ini adalah sebagai berikut :

1. Perangkat Keras

a. PC (Personal Computer) atau Laptop

Spesifikasi dari laptop HP 431 :

1. Prosesor : Intel ${ }^{\circledR}$ Core $^{\mathrm{TM}}$ i3 $-2310 \mathrm{M}(2.10 \mathrm{GHz})$

2. Sequence Diagram : 14.1' WXGA Brightview

3. Kartu grafis : Intel ${ }^{\circledR}$ HD Graphics Family

4. Memori : 2GB DDR3

5. Cakram keras : $640 \mathrm{~GB}$ HDD

6. Cakram optik: DVD \pm RW

7. Pembaca kartu : Card Reader 2 in 1

8. Jaringan nirkabel : Atheros AR8152/8158 PCI-E Fast Ethernet Controller

9. Kamera Web

10. Bluetooth

11. Perangkat masukan : Papan ketik standar + bantalan sentuh

12. Baterai : Lithium-ion

13. I/O Port : $3 \mathrm{x}$ USB, VGA, LAN, Audio

14. Nilai daya $: 19 \mathrm{~V}$

15. Tegangan : 100-240V $\sim 50-60 \mathrm{~V}$

b. Smartphone

Smartphone yang digunakan menggunakan sistem operasi Android. Smartphone digunakan sebagai pengujian aplikasi yang sudah jadi, sekaligus sebagai perantara pendistribusian aplikasi.

2. Perangkat Lunak

Perangkat lunak yang digunakan untuk membuat aplikasi multimedia pembelajaran berbasis mobile adalah

a. $\quad$ Microsoft Windows 7

Sistem Operasi dari laptop yang digunakan untuk membuat aplikasi mutimedia ini adalah Microsoft Windows 7.

b. MobiOne Studio

Perangkat lunak yang digunakan untuk membuat aplikasi multimedia ini adalah MobiOne.

c. Intel XDK

Perangkat lunak yang digunakan untuk membangun aplikasi multimedia ini ke dalam smartphone adalah Intel XDK.

d. Phonto

Perangkat lunak yang digunakan untuk merancang grafis pada beberapa ikon dalam aplikasi multimedia ini adalah Phonto.

\section{A. Hasil Penelitian}

\section{IMPLEMENTASI DAN PENGUJIAN}

1. Sequence Diagram halaman utama aplikasi Aplikasi pertama kali akan menampilkan halaman utama dengan 4 tombol menu. Terdapat 4 tombol menu utama yang meliputi :
a. Menu Belajar
b. Menu Mulai Latihan
c. Menu Petunjuk
d. Menu Tentang Sistem
beserta tombol keluar. Tampilan awal aplikasi ditunjukkan oleh Gambar 12.

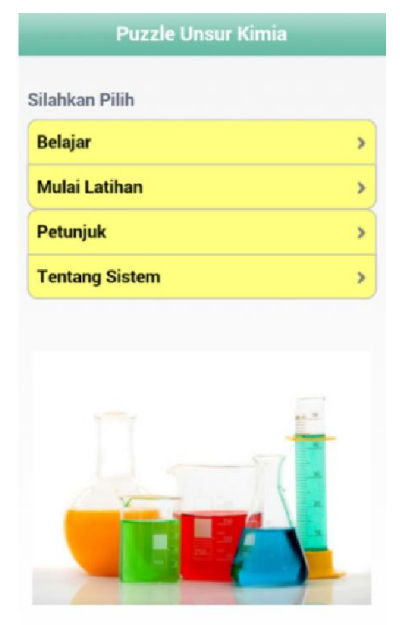

Gambar 12. Tampilan Awal Aplikasi

\section{Tampilan menu Belajar}

Aplikasi ini memiliki menu Belajar yang merupakan menu terpenting dalam aplikasi ini. Apabila menu Belajar dipilih, maka akan menampilkan materi kimia sistem periodik unsur yang meliputi golongan alkali, golongan alkali tanah, golongan alumunium, golongan karbon, golongan nitrogen, golongan oksigen, golongan halogen, golongan gas mulia, sistem periode 4 , dan unsurunsur metaloid.

Ikon golongan yang terdapat pada layar dapat dipilih (ditekan) untuk melihat materi kimia mengenai golongan tersebut. Tampilan menu Belajar apabila ditekan, ditunjukkan oleh Gambar 13 hingga Gambar 16.

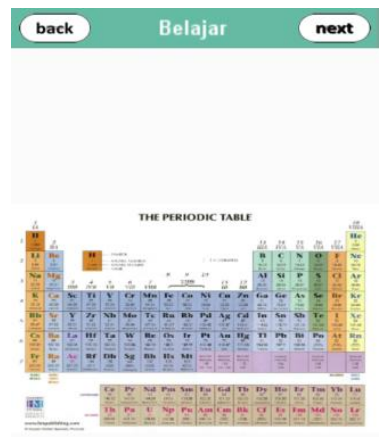

Gambar 13. Tabel Sistem Periodik Unsur 


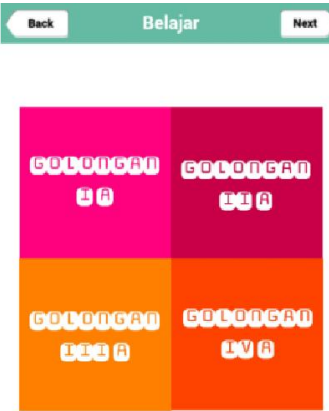

Gambar 14. Tampilan Menu Belajar1

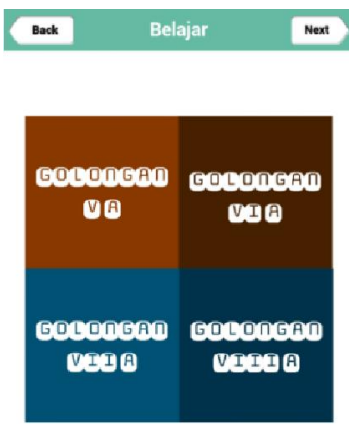

Gambar 15. Tampilan Menu Belajar2

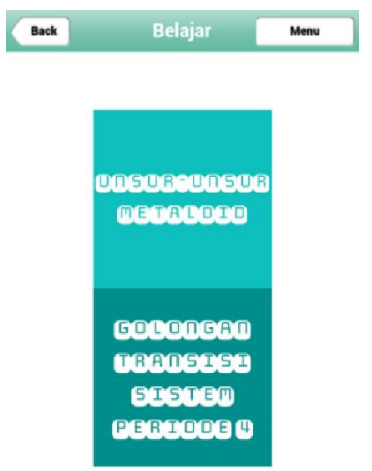

Gambar 16. Tampilan Menu Belajar3

3. Tampilan materi setiap golongan

Materi kimia yang ditampilkan pada setiap golongan meliputi nama latin, tahun ditemukannya unsur, sifat atom, sifat termodinamik, dan reaktifitas. Materi tersebut dijelaskan secara singkat dan dilengkapi dengan gambar diagram kulit elektron. Tampilan salah satu materi apabila tombol golonngan ditekan, ditunjukkan oleh Gambar 17.

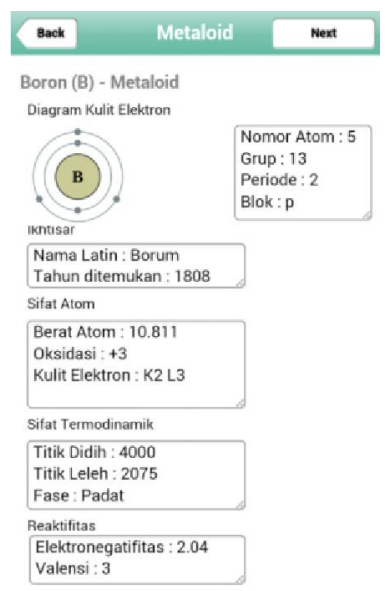

Gambar 17. Tampilan Materi.

4. Tampilan menu Mulai Latihan

Menu Mulai Latihan pada aplikasi ini berisi tekateki menebak unsur yang ada pada sistem periodik unsur dengan cara mencocokkan antara nama unsur dengan simbol unsur, simbol unsur dengan nama unsur, nama unsur dengan nomor atom, dan nama unsur dengan periode. Latihan ini bertujuan untuk melatih daya ingat terhadap materi yang telah disajikan pada aplikasi.

Terdapat 10 soal yang harus dijawab pada 4 level dan disediakan sebuah pertanyaan serta empat pilihan jawaban, jawaban yang ditebak akan mengarahkan pengguna ke halaman soal berikutnya dan mendapatkan score 0 apabila salah, dan mendapatkan score 1 apabila benar. Tampilan menu Mulai Latihan apabila ditekan, ditunjukkan oleh Gambar 18 hingga Gambar 22.

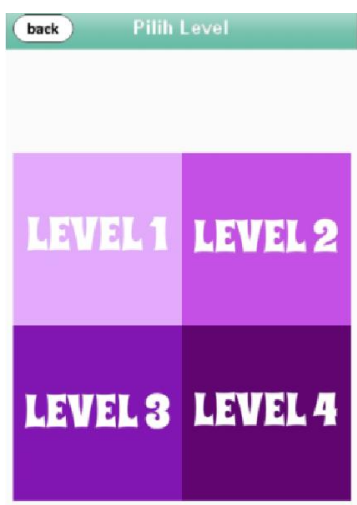

Gambar 18. Tampilan Menu Pilih Level. 


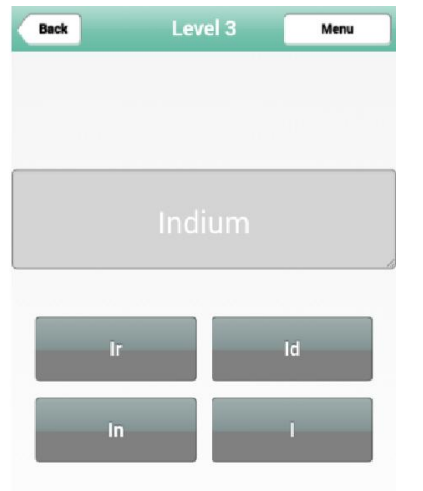

Gambar 19. Tampilan Soal pada Sublevel Nama-Simbol

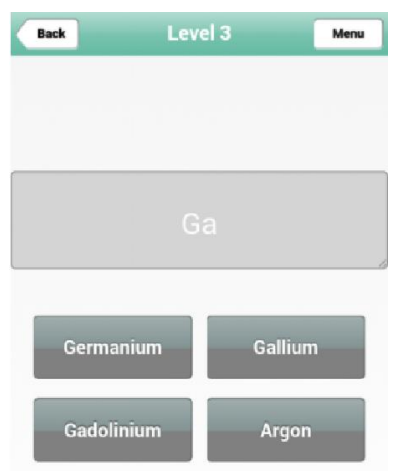

Gambar 20. Tampilan Soal pada Sublevel Simbol-Nama

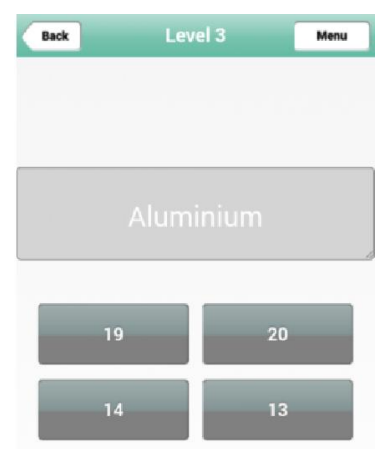

Gambar 21. Tampilan Soal pada Sublevel Nama-Nomor Atom

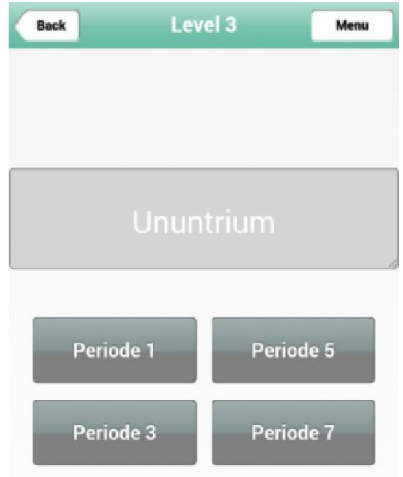

Gambar 22. Tampilan Soal pada Sublevel Nama-Periode

5. Tampilan menu Petunjuk

Menu Petunjuk pada aplikasi ini berisi mengenai informasi yang mempermudah pengguna dalam menggunakan fungsi-fungsi yang tersedia pada aplikasi multimedia pembelajaran ini agar dapat dimanfaatkan dengan baik. Tampilan menu Petunjuk apabila ditekan, ditunjukkan oleh Gambar 23.

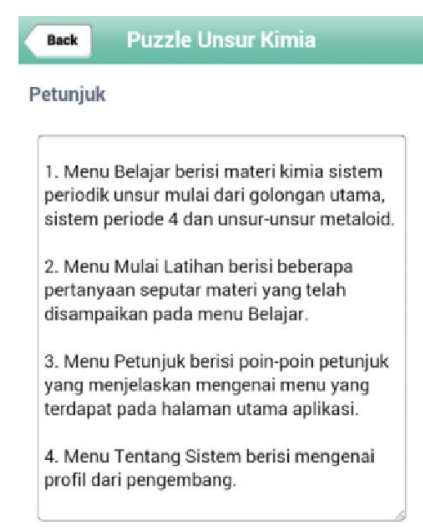

Gambar 23. Tampilan Menu Petunjuk.

\section{Tampilan menu Tentang Sistem}

Menu Tentang Sistem pada aplikasi ini berisi mengenai informasi mengenai pembuat aolikasi media pembelajaran ini. Tampilan menu Tentang Sistem apabila ditekan, ditunjukkan oleh Gambar 24. 


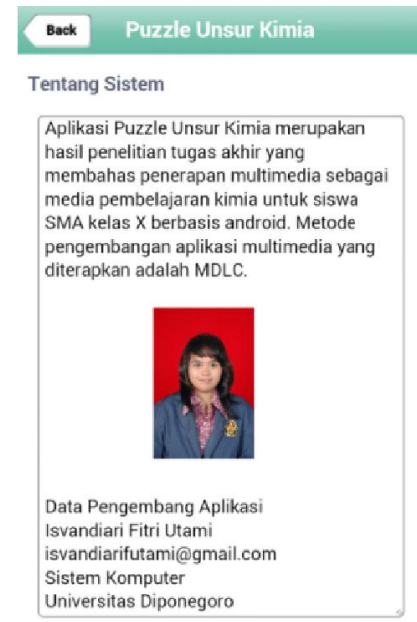

Gambar 24. Tampilan Menu Tentang Sistem.

B. Pengujian aplikasi menggunakan metode uji Whitebox

Pengujian aplikasi multimedia pembelajaran interaktif ini dilakukan dengan menggunakan metode uji whitebox. Dalam pengujian whitebox setiap fungsi yang ada akan diuji secara rinci jalur-jalur logika yang ada. Pengujian akan dilakukan untuk masing-masing jalur, cabang dan perintah. Fungsi-fungsi dari aplikasi multimedia pembelajaran interaktif yang akan dilakukan pengujian sistem diantaranya adalah pada halaman utama beserta setiap navigasi menu beserta fitur-fitur yang terdapat pada menu tersebut.

Pengujian sistem pertama kali akan dilakukan pada Tampilan pertama yang akan dilihat oleh pengguna ketika mengakses aplikasi teka-teki unsur kimia sebagai media pembelajaran interaktif berbasis android yaitu halaman utama. Diagram alir untuk proses pengujian yang pertama ditunjukkan pada Gambar 25 dan Flowgraph pada Gambar 26.

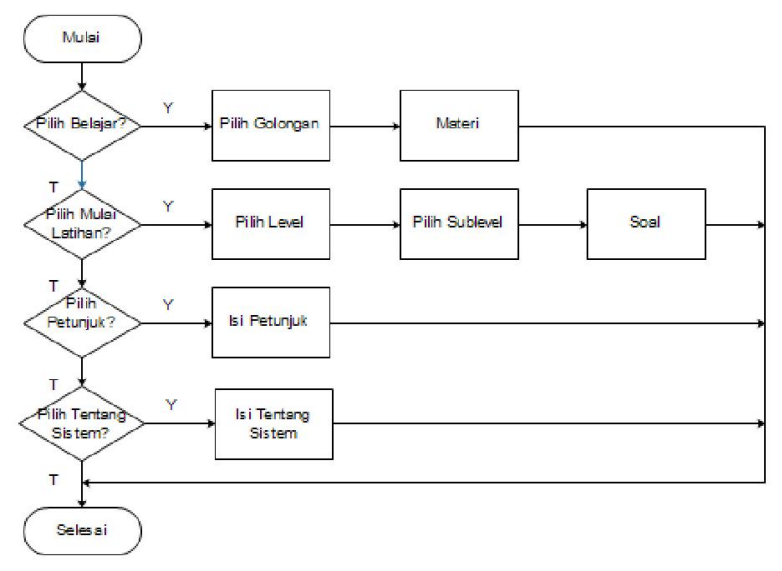

Gambar 25. Diagram Alir Halaman Utama

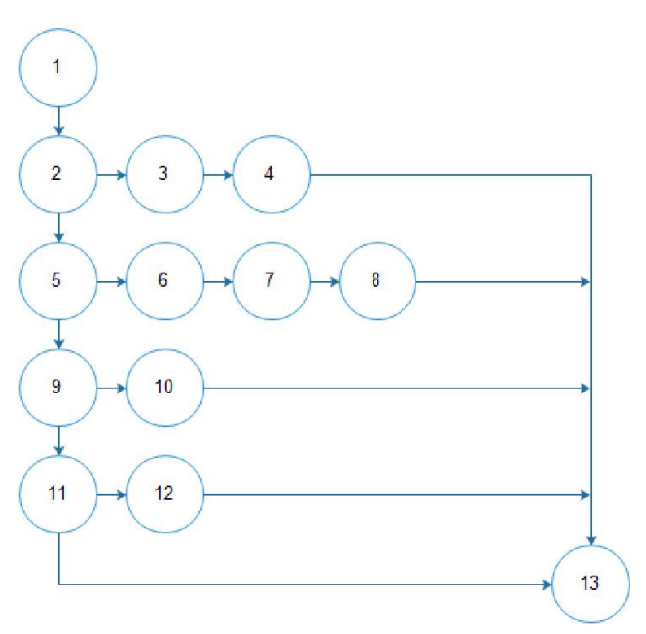

Gambar 26. Flowgraph Halaman Utama

Tabel 1. Jalur Proses pada Halaman Utama

\begin{tabular}{|c|l|l|}
\hline Jalur & \multicolumn{1}{|c|}{ Tahapan } & \multicolumn{1}{|c|}{ Keterangan } \\
\hline 1 & $1-2-3-4-13$ & $\begin{array}{l}\text { Masuk ke halaman utama, } \\
\text { memilih menu belajar, } \\
\text { memilih materi golongan } \\
\text { yang akan dipelajari, materi } \\
\text { golongan tampil, selesai }\end{array}$ \\
\hline 2. & $\begin{array}{l}1-2-5-6-7-8- \\
13\end{array}$ & $\begin{array}{l}\text { Masuk ke halaman utama, } \\
\text { memilih menu mulai latihan, } \\
\text { memilih level dan sublevel } \\
\text { kemudian menjawab } \\
\text { pertanyaan, selesai }\end{array}$ \\
\hline 3 & $1-2-5-9-10-13$ & $\begin{array}{l}\text { Masuk ke halaman utama, } \\
\text { memilih menu petunjuk, } \\
\text { menu petunjuk tampil, selesai }\end{array}$ \\
\hline 4 & $\begin{array}{l}1-2-5-9-11- \\
12-13\end{array}$ & $\begin{array}{l}\text { Masuk ke halaman utama, } \\
\text { memilih menu tentang sistem, } \\
\text { menu tentang sistem tampil, } \\
\text { selesai }\end{array}$ \\
\hline 5 & $1-2-5-9-11-13$ & $\begin{array}{l}\text { Masuk ke halaman utama, } \\
\text { tidak memilih menu, selesai. }\end{array}$ \\
\hline
\end{tabular}

Ketika menu beranda diklik atau aplikasi pertama kali dibuat maka sistem akan mengarahkan ke Halaman Utama. Pada halaman utama ini terdapat beberap tombol yang dapat dipilih oleh pengguna, diantaranya adalah tombol belajar, tombol mulai latihan, tombol petunjuk, dan tombol tentang sistem.

Dari Flowgraph pada Gambar 26 didapatkan nilai cyclomatic complexity $\mathrm{V}(\mathrm{G})=\mathrm{E}-\mathrm{N}+2$ atau $\mathrm{V}(\mathrm{G})=\mathrm{P}+1$, dimana $\mathrm{E}$ merupakan jumlah Edge, $\mathrm{N}$ merupakan jumlah Node, sedangkan $\mathrm{P}$ merupakan jumlah cabang, sehingga didapatkan $\mathrm{E}=16, \quad \mathrm{~N}=13$. dan $\mathrm{P}=4$. Maka $\mathrm{V}(\mathrm{G})=16-13+2=5$ atau $\mathrm{V}(\mathrm{G})=4+1=5$.

Dengan didapatkannya nilai cyclometic complexity (CC) sebesar 5, maka akan didapatkan hubungan dengan resiko yang ada dalam suatu prosedur, yaitu sistem yang dibangun merupakan sistem dengan tipe prosedur yang 
terstruktur dengan baik dan juga stabil, serta memiliki resiko yang rendah.

Kasus pengujian selanjutnya adalah pada halaman "Mulai Latihan". Diagram alir pada halaman "Mulai Latihan" ditunjukkan pada Gambar 27 dan Flowgraph pada Gambar 28.

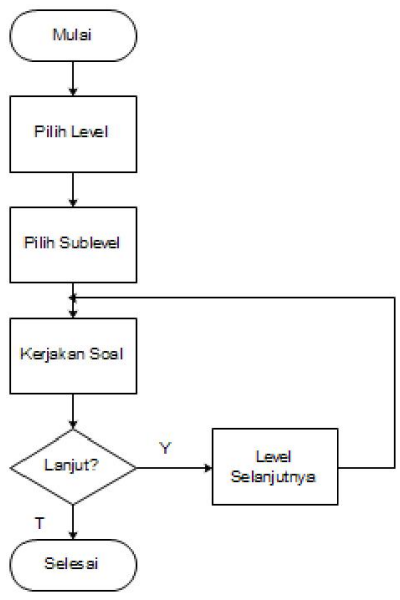

Gambar 27. Diagram Alir Menu Mulai Latihan

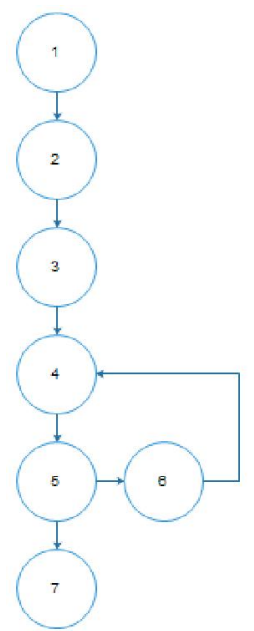

Gambar 28. Flowgraph Menu Mulai Latihan

Tabel 2. Jalur Proses Menu Mulai Latihan

\begin{tabular}{|c|l|l|}
\hline Jalur & \multicolumn{1}{|c|}{ Tahapan } & \multicolumn{1}{c|}{ Keterangan } \\
\hline 1. & $1-2-3-4-5-6-4-5-$ & $\begin{array}{l}\text { Masuk ke halaman mulai } \\
\text { latihan, memilih level dan } \\
\text { sublevel, mengerjakan soal } \\
\text { pada sublevel 1 hingga } \\
\text { sublevel 4, selesai. }\end{array}$ \\
\hline 2. & $1-2-3-4-5-7$ & $\begin{array}{l}\text { Masuk ke halaman mulai } \\
\text { latihan, memilih level dan } \\
\text { sublevel, mengerjakan soal } \\
\text { pada salah satu sublevel, } \\
\text { selesai. }\end{array}$ \\
\hline
\end{tabular}

Dari Flowgraph pada Gambar 28 didapatkan nilai cyclomatic complexity $\mathrm{V}(\mathrm{G})=\mathrm{E}-\mathrm{N}+2$ atau $\mathrm{V}(\mathrm{G})=\mathrm{P}+1$, dimana E merupakan jumlah Edge, $\mathrm{N}$ merupakan jumlah Node, sedangkan $\mathrm{P}$ merupakan jumlah cabang, sehingga didapatkan $\mathrm{E}=7, \mathrm{~N}=7$. dan $\mathrm{P}=1$. Maka $\mathrm{V}(\mathrm{G})=7-7+2=2$ atau $\mathrm{V}(\mathrm{G})=1+1=2$. Dengan didapatkannya nilai cyclometic complexity (CC) sebesar 2, maka akan didapatkan hubungan dengan resiko yang ada dalam suatu prosedur, yaitu sistem yang dibangun merupakan sistem dengan tipe prosedur yang sederhana dan memiliki resiko yang rendah.

\section{KESIMPULAN}

Kesimpulan dari penelitian tugas akhir ini adalah sebagai berikut:

1. Aplikasi teka-teki unsur kimia sebagai media pembelajaran kimia interaktif bagi siswa SMA kelas $\mathrm{X}$ merupakan sebuah aplikasi berbasis android yang memiliki fitur inti dapat melakukan pembelajaran pada materi kimia sistem periodik unsur melalui 10 pilihan materi golongan dan 3 level pertanyaan yang diberikan sistem kepada pengguna.

2. Metode yang dilakukan pada aplikasi pembelajaran ini adalah dengan MDLC (Multimedia Development Life Cycle). Dalam menggunakan metode tersebut, informasi yang diperoleh dari materi-materi kimia pada kurikulum 2006 diterjemahkan ke dalam halaman-halaman pembelajaran dan selanjutnya dibuat suatu latihan soal.

3. Pengujian yang dilakukan pada aplikasi ini adalah menggunakan metode whitebox dan memperoleh hasil cyclomatic complexity yang diperoleh sudah sesuai dengan tabel jalur proses yang dibuat, sehingga dapat disimpulkan bahwa logika yang diberikan untuk sistem sudah sesuai dengan kebutuhan sistem.

\section{SARAN}

Saran yang diberikan dalam upaya pengembangan sistem yang lebih baik dikemudian hari diantaranya:

1. Penambahan unsur-unsur yang lain yang lebih lengkap selain unsur-unsur utama dan unsur-unsur transisi periode 4 .

2. Penambahan fitur perbesar untuk memperjelas Sequence Diagram gambar pada aplikasi.

3. Pengembangan dengan variasi soal yang lebih banyak agar nantinya dapat menambah pemahaman terhadap materi sistem periodik unsur kimia.

\section{DAFTAR PUSTAKA}

[1] Budi Sutedjo Dharma Oetomo. 2002. e-Education. Konsep, Teknologi dan Aplikasi Internet Pendidikan. Yogyakarta: Penerbit ANDI.

[2] Hofstetter, Fredt. 2001. Multimedia Literacy. Third Edition. McGraw-Hill: Irwin. 
[3] A. Santoso, E. Noviandi and I. Pradesan. "Rancang Bangun Aplikasi Pembelajaran Organ Tubuh Berbasis Augmented Reality". 3.

[4] O. D. Nurhayati and R. I. 2011. Aplikasi Multimedia dalam Desain Pembelajaran Mata Kuliah Multimedia di Jurusan Sistem Komputer UNDIP, Semarang: tidak diterbitkan.

[5] Murtiwiyati dan Glenn Lauren. 2013. "Rancang Bangun Aplikasi Pembelajaran Budaya Indonesia Untuk Anak Sekolah Dasar Berbasis Android". Jurnal Komputasi, 12, 2-3.

[6] http://Genuitec.com. Diakses pada tanggal 7 Juli 2015

[7] https://software.intel.com/en-us/xdk/docs/intel-xdkguided-tutorial Diakses pada tanggal 25 Oktober 2015

[8] Sutopo, Ariesto Hadi. 2003. Multimedia Interaktif Dengan Flash. Jakarta: Penerbit Graha Ilmu.

[9] Purba, Michael. 2006. Kimia Untuk SMA Kelas XI. Jakarta: Penerbit Erlangga 